\title{
THE GEOGRAPHICAL AND ALTITUDINAL DISTRIBUTION OF THE POLLEN WASP CERAMIUS HISPANICUS DUSMET, 1909 (HYMENOPTERA, VESPIDAE), ENDEMIC ON THE IBERIAN PENINSULA
}

\author{
V. Mauss $(*) \&$ L. Castro $(* *)$
}

\begin{abstract}
Ceramius hispanicus Dusmet appears to be restricted to an area of ca. $21 \times 10^{4} \mathrm{~km}^{2}$ basically in central and north-eastern Spain. The species has been recorded from 32 localities. The altitudinal distribution ranges from 150 to $1300 \mathrm{~m}$ above sea level. C. hispanicus seems to be restricted to the meso- and supramediterranean story of vegetation. It has been recorded from 13 different vegetation series. The proportion of basophilic vegetation series of the localities is $65 \%$. Climatic conditions at most of the localities can be characterised as moderately hot, with a cold period in winter and an annual mean precipitation of between 300 and $500 \mathrm{~mm}$. The flight period of the imagines correlates with altitude, lasting from the beginning of May to the end of July.
\end{abstract}

Key words: Hymenoptera, Vespidae, Masarinae, biogeography, habitat, palaearctic.

\section{RESUMEN}

La distribución geográfica y altitudinal de la avispa masarina Ceramius hispanicus Dusmet, 1909 (Hymenoptera, Vespidae) endémica de la Península Ibérica

Ceramius hispanicus Dusmet tiene aparentemente un área de distribución de unos $21 \times 10^{4} \mathrm{~km}^{2}$, restringida básicamente al centro y noreste de España. En el presente trabajo se cita la especie de 32 localidades. Su distribución altitudinal está comprendida entre los 150 y los 1300 metros. C. hispanicus parece estar restringido a los pisos bioclimáticos meso- y supramediterráneo. Se ha registrado su presencia en 13 series de vegetación diferentes. El porcentaje de localidades con serie de vegetacíon basófila es del $65 \%$. Las condiciones climáticas de la mayor parte de las localidades se pueden caracterizar como moderadamente cálidas, con un periodo frío en invierno y una precipitación media anual de entre 300 y $500 \mathrm{~mm}$. El periodo de vuelo de los imagos está en relación con la altitud, y va desde principios de Mayo a finales de Julio.

Palabras clave: Hymenoptera, Vespidae, Masarinae, biogeografía, hábitat, Paleártico.

\section{Introduction}

The bionomy of Ceramius hispanicus Dusmet 1909 has recently been investigated in the Sierra de Albarracín, where a large population exists in the Barranco de Zorita at an altitude of $1200 \mathrm{~m}$ (Mauss \& Müller, 2000). At this locality, the species inhabits an area covered by sparse montane forest dominated by trees and scrub of different juniper species. Female wasps collect water from the edge of little streams or ponds. The water is used to soften hard soil during excavation of a fossorial nest. As in other members of the Masarinae, brood cells are provisioned with pollen. The main pollen sources for $C$. hispanicus at Barranco de Zorita are Helianthemum (Cistaceae), Coris (Primulaceae), several species of Lamiaceae, and Lotus (Fabaceae) (Mauss \& Müller, 2000).

\footnotetext{
* Institut für Landwirtschaftliche Zoologie \& Bienenkunde, Rheinische Friedrich-Wilhelms-Universität Bonn, Melbweg 42, D53127 Bonn, Germany, ULT402@uni-bonn.de
}

** Sanz Gadea 9, E-44002 Teruel, Spain 
Although activity of males and females of $C$. hispanicus can be very high at water sites (cf. Mauss \& Müller, 2000), surprisingly few records of the species have been published. Specimens have only been recorded from 9 localities in the Spanish provinces of Barcelona, Córdoba, Cádiz, Madrid, Valencia and Valladolid (Bischoff, 1933; Ceballos, 1956; Dusmet, 1909, 1935, 1951; Giner-Marí, 1945: 109; Richards, 1962: 107). Therefore the geographical distribution of $C$. hispanicus appears to be little known. Moreover the flight period and the ecological potency of the species (sensu Schwerdtfeger, 1963: 39 ) with regard to e.g. altitudinal range, vegetation and climatic conditions are completely unknown.

\section{Material and Methods}

Seventy-two public collections, including the main European ones, were questioned about their collections of species of Ceramius. Some private collectors were in addition consulted and enquiries were made in newsletters for hymenopterists. Altogether 261 specimens (225 females and 36 males) of $C$. hispanicus were detected including 16 probable paratypes (indicated by identification labels in the handwriting of Dusmet, collecting date previous to 1908 and from localities mentioned in the original description; in addition four of these specimens were labelled as "cotypes"). All males were genitalized. Specimens

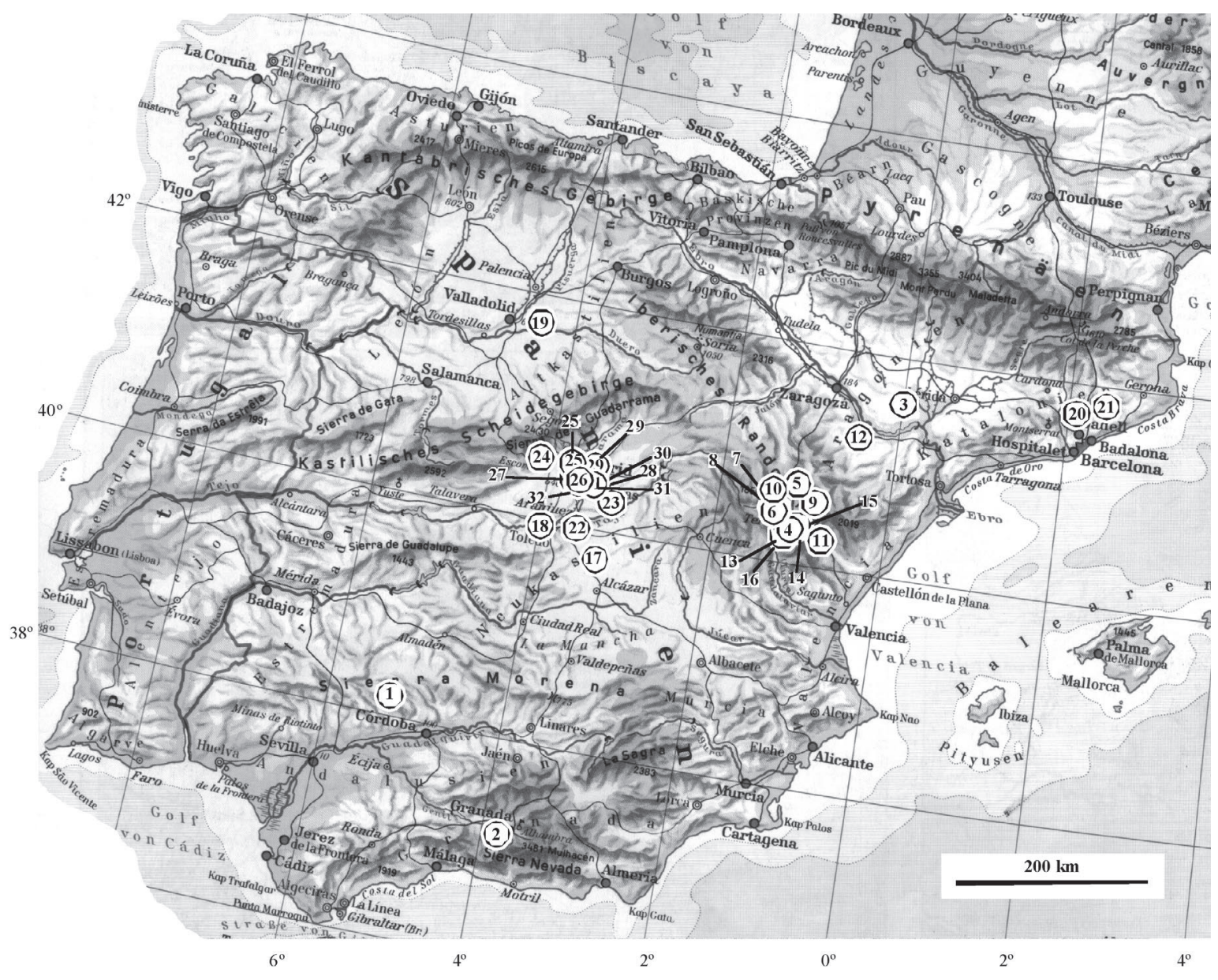

Fig. 1. - The distribution of Ceramius hispanicus (number of specimens per site not taken into account; localities numbered as in Tab. 1).

Fig. 1.- Distribución de Ceramius hispanicus (no se ha tenido en cuenta el número de ejemplares de cada localidad; las localidades aparecen numeradas como en la Tabla $1 ; m$ a.s.l. = metros sobre el nivel del mar; story of vegetation= piso bioclimático). 
were identified with a stereo microscope. Identification was based on the key by Richards (1962: 83-85) and comparison with the probable paratypes (all of the 71 specimens determined as $C$. hispanicus by Dusmet had been correctly identified). All specimens were individually assigned a serial number (= dbM No.) in the Ceramius database of V. Mauss (FileMaker Pro ${ }^{\mathrm{TM}}$ for Apple Macintosh) and this was given on the identification label. Label information of each specimen was entered into the database. The following abbreviations are used to identify public collections in which specimens are located:

$\mathrm{AMNH}=$ American Museum of Natural History, New York

$\mathrm{BMNH}=$ Natural History Museum, London

$\mathrm{ETHZ}=$ Institut für Pflanzenwissenschaften ETH-Zentrum NW, Zürich

MNMS $=$ Museo Nacional de Ciencias Naturales, Madrid

$\mathrm{MZB}=\quad$ Museu de Zoologia, Barcelona

NHMW $=$ Naturhistorisches Museum Wien

$\mathrm{RMNH}=$ National Natuurhistorisch Museum Leiden

ZMAN= Zoölogisch Museum Amsterdam.

Private collections are indicated by the surname of the owner (L. Castro; V. Mauss; J. Schmitz, Göttingen; D. Schneider, Bonn).

Records were localised using Diccionario geográfico de España (1956-1961), Michelin ${ }^{\circledR}$ Carte Routière et Touristique 1:400000 España (Nos. 443, 444, 445, 446), Ministerio de Defensa (1999), Nuevo Atlas de España (1961) and indications by Dusmet (1935). If the altitude of a locality was not given on the label, it was normally taken from the Cartografía/Mapa Militar de España 1:50000 (contour lines $20 \mathrm{~m}$ ), and, in a few cases, the Cartografía/Mapa Militar de España 1:200000 had to be used instead (contour lines $100 \mathrm{~m}$ ). The altitude of localities situated between two contours is given as the mean of both altitudes. The localities were classified as belonging to one of the vegetation series and the phytoclimatic subregions of the Iberian Peninsula according to the vegetation maps of Rivas-Martínez (1987). If a locality was situated close to the border between two vegetation series, it was classed as belonging to both series but weighted by a factor of 0.5 each. Story of vegetation, climatic conditions and soil type of each locality were deduced from the vegetation series or phytoclimatic subregions according to Rivas-Martínez (1987) and Allué Andrade (1987) respectively.

\section{Results}

Ceramius hispanicus has been recorded from 32 localities mainly in central and north-eastern Spain

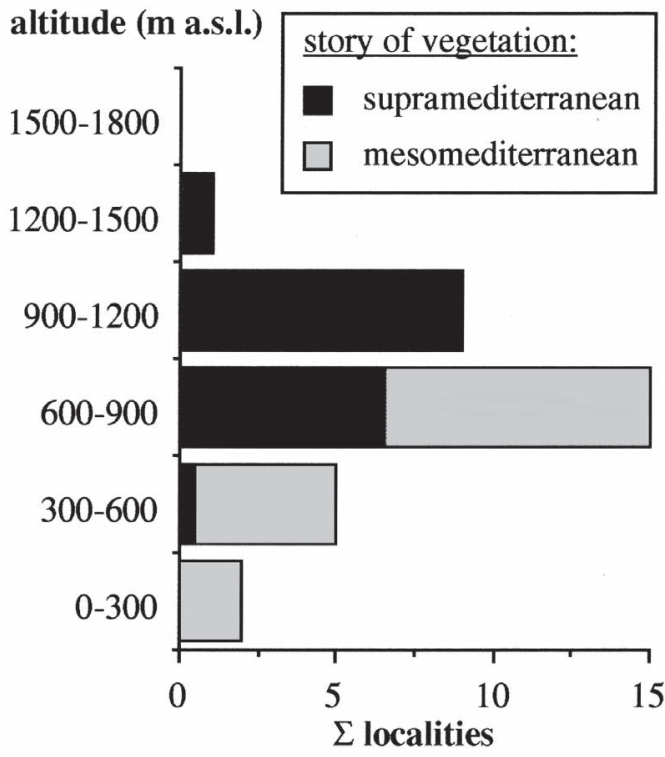

Fig. 2.- Altitude and story of vegetation of the localities of Ceramius hispanicus on the Iberian Peninsula (story of vegetation reconstructed from coordinates after Rivas-Martínez, 1987, see Tab. 1).

Fig. 2.- Altitudes y pisos bioclimáticos de las localidades de Ceramius hispanicus de la Península Ibérica (los pisos bioclimáticos se han deducido a partir de las coordenadas geográficas y según Rivas-Martínez, 1987, ver Tabla 1).

(Tab. 1, Fig. 1). The species occurs between $150 \mathrm{~m}$ and $1300 \mathrm{~m}$ above sea level (Fig. 2) with a median of $715 \mathrm{~m}$. The localities are exclusively within the supra- or mesomediterranean story of vegetation (Fig. 2). Ceramius hispanicus has been recorded from 13 different vegetation series. Dominant series are the Bupleuro rigidi-Querceto rotundifoliae sigmetum, the Junipero thuriferae-Querceto rotundifoliae sigmetum and the Junipereto hemisphaericothuriferae sigmetum (Fig. 3a). Sixty-five \% of the localities are situated in basophilic vegetation series (Fig. 3a), and more than $75 \%$ of the inhabited vegetation series are associated with Quercus rotundifolia Lam. (cf. Rivas-Martínez, 1987). Following the concept of Allué Andrade (1987), the prevailing phytoclimatic conditions at $90 \%$ of the localities can be characterised as typical mediterranean, moderately hot and with a cold period in winter (Fig. 3b). At only three localities is mean annual precipitation above $650 \mathrm{~mm}$; at two of these, subhumid mediterranean climate exists. Two single specimens have been recorded from areas with a subarid climate in the Ebro depression and the Baetic mountains. The 
Table 1.- Records of Ceramius hispanicus from the Iberian Peninsula, ordered after Spanish provinces (altitudes in parenthesis were reconstructed from coordinates; phytoclimate and vegetation were reconstructed from coordinates after Rivas-Martínez, 1987).

Tabla 1.- Citas de Ceramius hispanicus en la Península Ibérica, ordenadas por provincias (las altitudes que se dan entre paréntesis se han calculado a partir de las coordenadas geográficas; los datos fitoclimáticos y de vegetación se han deducido según dichas coordenadas y de acuerdo con Rivas-Martínez, 1987).

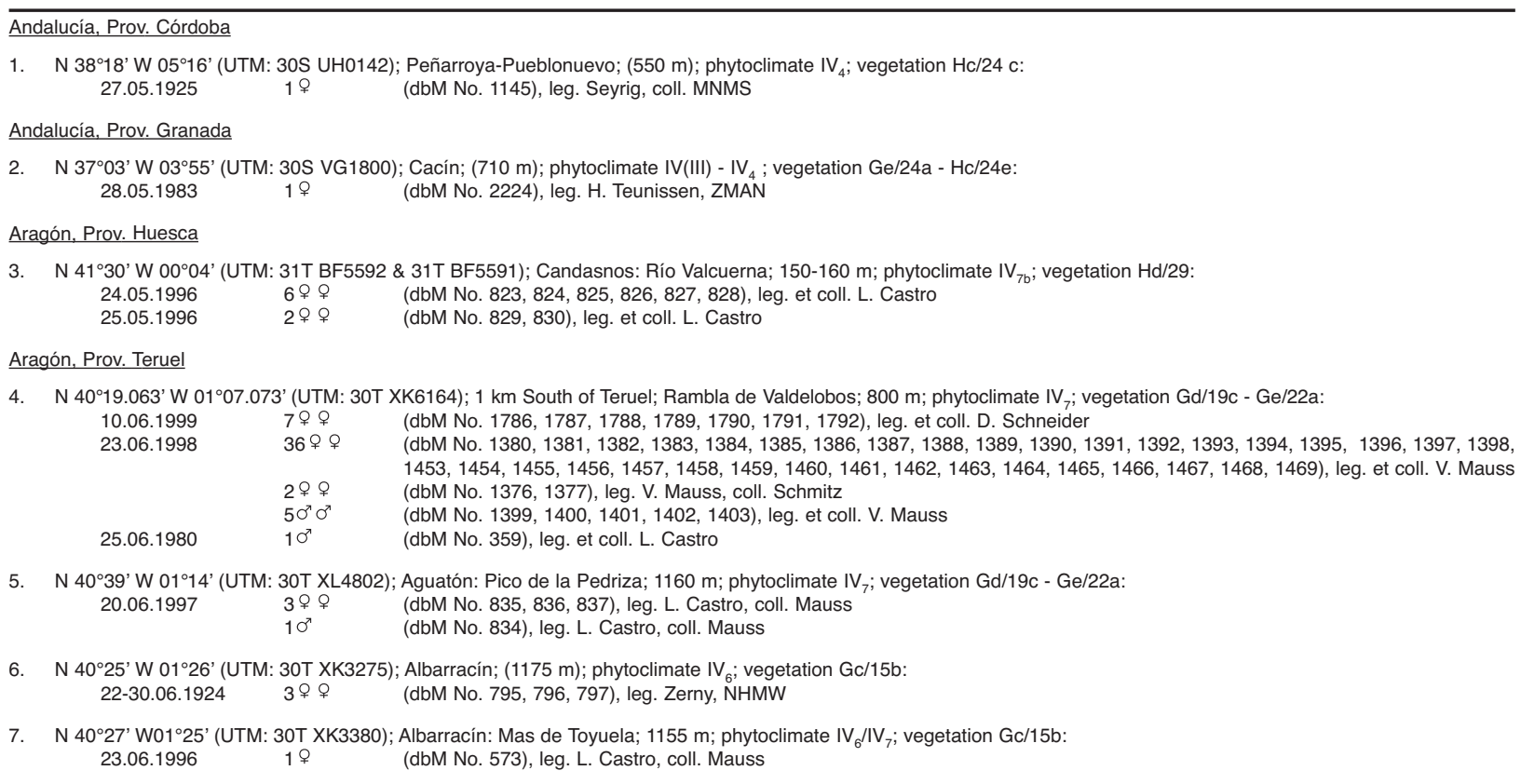

8. N $40^{\circ} 27.334 \mathrm{~W} 01^{\circ} 26.402^{\prime}$ (UTM: 30T XK3279); ca. $6 \mathrm{~km} \mathrm{~N}$ of Albarracín, Barranco de Zorita on the NE slope of the Vallejo Largo; $1238 \mathrm{~m}$; phytoclimate IV ${ }_{6}$; vegetation Gc/15b:

$\begin{array}{lll}\text { 15b: } & & \\ 19.06 .1998 & 4 \% \circ & \text { (dbM No. 1421, 1430, 1432, 1475), leg. et coll. V. Mauss } \\ & 2 \sigma^{7} \sigma^{7} & \text { (dbM No. 1418, 1437), leg. et coll. V. Mauss } \\ 20.06 .1998 & 1 \% & \text { (dbM No. 1424), leg. et coll. V. Mauss } \\ & 30^{7} \sigma^{7} & \text { (dbM No. 1435, 1441, 1442), leg. et coll. V. Mauss } \\ 22.06 .1998 & 40^{7} \sigma^{7} & \text { (dbM No. 1426, 1427, 1428, 1476), leg. et coll. V. Mauss } \\ 23.06 .1996 & 5 \% \bigcirc & \text { (dbM No. 591, 592, 593, 594, 595), leg. L. Castro, coll. Mauss } \\ & 20^{7} \sigma^{7} & \text { (dbM No. 589,590), leg. L. Castro, coll. Mauss } \\ 26.06 .1998 & 4 \%+ & \text { (dbM No. 1419, 1422, 1431, 1438), leg. et coll. V. Mauss }\end{array}$

9. N 40³3' W 0102' (UTM: 30T XK6793); Alfambra: Barranco Altaban; (1050 m); phytoclimate IV ${ }_{6}$; vegetation Ge/22a: $\begin{array}{lll}06.06 .1999 & 1 \% & \text { (dbM No. 1796), leg. et coll. D. Schneider } \\ & 10^{7} & \text { (dbM No. 1797), leg. et coll. D. Schneider }\end{array}$

10. N $40^{\circ} 35.941 \mathrm{~W} 01^{\circ} 25.91^{\prime}$ (UTM: 30T XK3395); Almohaja; 1183m; phytoclimate IV $\mathrm{V}_{7}$; vegetation Ge/22a 13.06.1997 2 2우 $\quad$ (dbM No. 831, 832), leg. L. Castro, coll. Mauss 15.06.1999 $\quad 10 \quad$ (dbM No. 833), leg. L. Castro, coll. Mauss

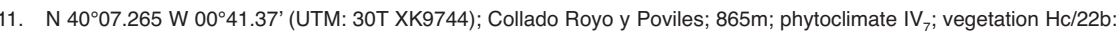
28.05.1999 $\quad 1$ 우 (dbM No. 1795), leg. et coll. D. Schneider

12. N $41^{\circ} 13^{\prime}$ W $00^{\circ} 23^{\prime}$ (UTM: $30 T^{\prime}$ YL1966); Jatiel; $195 \mathrm{~m}$; phytoclimate IV(VII); vegetation Hd/29: 09.06.1996 1 ( 1 (dbM No. 816) leg. et coll. L. Castro

13. N 40¹9' W 0108' (UTM: 30T XK5863); Villaspesa: Rambla Barrachina; $875 \mathrm{~m}$; phytoclimate IV ${ }_{7}$; vegetation Gd/19c - Ge/22a: 10.06.1999 2 우 $\quad$ (dbM No. 1798, 1799), leg. et coll. D. Schneider

14. N 40¹9' W 0106' (UTM: 30T XK6165); Teruel: Rambla Franquia; 910-925 m; phytoclimate IV $;$; vegetation Gd/19c - Ge/22a:

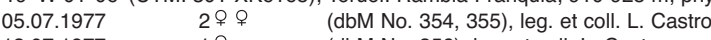
13.07.1977 $\quad 1$ 요 $\quad$ (dbM No. 356), leg. et coll. L. Castro

15. N 40²2' W 0103' (UTM: 30T XK6569); Valdecebro; $1000 \mathrm{~m}$; phytoclimate IV ; vegetation Ge/22a: 09.06.1999 13 우 (dbM No. 1763, 1764, 1765, 1766, 1767, 1768, 1769, 1770, 1771, 1772, 1773, 1774, 1775), leg. et coll. D.Schneider 19.06.1999 8 우 (dbM No. 1776, 1777, 1778, 1779, 1780, 1781, 1782, 1783), leg. et coll. D. Schneider 21.06.1998 $\quad 4$ 우우 (dbM No. 1478, 1479, 1480, 1481), leg. L. Castro, coll. Mauss (dbM No. 1369, 1370), leg. L. Castro, coll. Mauss

16. N 40¹3.338' W 0109.829' (UTM: 30T XK5654); Villel: Mas de Cajero; 840 m; phytoclimate IV ; vegetation Gd/19c - Ge/22a: 10.06.1999 $\quad 3$ 우 우 $\quad$ (dbM No. 1800, 1801, 1802, ), leg. et coll. D. Schneider 12.06.1999 $\quad 1$ 우 $\quad$ (dbM No. 1803), leg. et coll. D. Schneider 
Castilla - La Mancha, Prov. Toledo

17. N 39॰43' W $03^{\circ} 19^{\prime}$ (UTM: 30 S VK7005); Lillo; $690 \mathrm{~m}$; phytoclimate $\mathrm{IV}_{7 \mathrm{c}}$; vegetation $\mathrm{Hc} / 22 \mathrm{~b}$ : $\begin{array}{lll}02.06 .1996 & 1 \% & \text { (dbM No. 817, 818, 819, 820, 821), leg. et coll. L. Castro }\end{array}$

18. N 3952' W $04^{\circ} 02^{\prime}$ (UTM: 30S VK1113); Toledo; (530 m); phytoclimate $\mathrm{IV}_{7 \mathrm{c}}$; vegetation $\mathrm{Hc} / 22 \mathrm{~b}-\mathrm{Hc} / 24 \mathrm{c}$ 09.-10.06.1968 $10^{7} \quad$ (dbM No. 358), leg. PMF Verhoeff, RMNH

Castilla y León, Prov. Valladolid

19. N 4142' W 0419' (UTM: 30T UM9017); Jaramiel (= Los Jaramieles); (850 m); phytoclimate IV ${ }_{7}$; vegetation Gd/19b: no date $\quad 1$ ( 1 (bM No. 353), leg. Dusmet, RMNH 06.07.1910 1 ( $19 \quad$ (dbM No. 798), leg. Dusmet, NHMW

3 우 우 (dbM No. 884, 885, 898), leg. Dusmet, ETHZ

46 우 우 (dbM No. 1128, 1129, 1130, 1131, 1132, 1133, 1135, 1136, 1137, 1138, 1251, 1620, 1621, 1622, 1623, 1624, 1625, 1626, 1627, $1628,1629,1630,1631,1632,1633,1634,1635,1636,1637,1638,1639,1640,1641,1642,1643,1644,1645,1646,1647,1648$, $1628,1629,1630,1631,1632,1633,1634,1635,1636,1637$,

$\begin{array}{lll} & 2 \% \text { o } & \text { (dbM No. 1665, 1666) leg. Dusmet, AMNH } \\ & 4 \% \text { 우 } & \text { (dbM No. 1756, 1757, 1758, 1759), leg. Dusmet, MZB } \\ 21.07 .1905 & 1 \% & \text { (dbM No. 1134), leg. Dusmet, MNMS }\end{array}$

1 (dbM No. 1755), leg. Dusmet, MZB

Cataluña, Prov. Barcelona

20. N 4149' E 02¹3' (UTM: 31T DG3429); Balenyá; (590 m); phytoclimate IV(VI); vegetation Ge/21a - Hc/21b:

$\begin{array}{lll}16.06 .1934 & 1 \% & \text { (dbM No. 1747), leg. Vilarrubia, MZB } \\ 18.06 .1929 & 1 \% & \text { (dbM No. 1749), leg. Vilarrubia, MZB } \\ 03.07 .1933 & 1 \% & \text { (dbM No. 1745), leg. Vilarrubia, MZB } \\ 04.07 .1933 & 1 \% & \text { (dbM No. 1746), leg. Vilarrubia, MZB } \\ 06.07 .1933 & 3 \% \text { 우 } & \text { (dbM No. 1751, 1752, 1753), leg. Vilarrubia, MZB } \\ 16.07 .1934 & 1 \% & \text { (dbM No. 1750), leg. Vilarrubia, MZB } \\ 17.07 .1934 & 1 \% & \text { (dbM No. 1748), leg. Vilarrubia, MZB }\end{array}$

21. N 41 $49^{\prime}$ E 02²0' (UTM: 31T DG4429); Montseny; Camino del Brull a Collformic.; (992,5 m); phytoclimate IV(VI); vegetation Ge/21a: 29.06.1939 1 (dbM No. 1754), leg. A. Vilarrubia, MZB

Madrid

22. N $40^{\circ} 02^{\prime}$ W $03^{\circ} 37^{\prime}$ (UTM: 30T VK4731); Aranjuez; (500 m); phytoclimate $\mathrm{IV}_{7}$; vegetation $\mathrm{Hc} / 22 \mathrm{~b}$ : 20.05.1910 19 (dbM No. 1143), leg. G. Mercet, MNMS

23. N 4007' W 0320' (UTM: 30T VK7240); Belmonte de Tajo: Fuente de los Perales; 720 m; phytoclimate IV ${ }_{7}$; vegetation Gd/19b: 01.06.1996 1 ( 1 (dbM No. 809), leg. et coll. L. Castro

24. N 40³4' W 0408' (UTM: 30T VK0491); El Escorial; (920 m); phytoclimate IV ; vegetation Gb/18a: 24.06.1941 1 1 $\quad$ (dbM No. 1151), leg. J. Dusmet, MNMS

25. N 40 $31^{\prime}$ ' W $03^{\circ} 47^{\prime}$ (UTM: 30T VK3385); El Pardo; (620 m); phytoclimate IV ; vegetation Ge/24ab: 08.05.1920 6 우우의 (dbM No. 1147, 1148,1149,1150,1655, 1656), leg. Dusmet, MNMS

26. N 40²5' W $03^{\circ} 43^{\prime}$ (UTM: 30T VK3974); Madrid; (650 m); phytoclimate IV ; vegetation $\mathrm{Hc} / 22 \mathrm{~b}$ : no date $20^{7} \sigma^{7} \quad$ (dbM No. 1163, 1657), leg. Dusmet, MNMS $\begin{array}{lll}09.06 .1919 & 10^{7} & \text { (dbM No. 1164), leg. A. Sanz, MNMS } \\ 10^{7} & \text { (dbM No. 1166), leg. Dusmet, MNMS }\end{array}$ 16.06.1912 1 은 $\quad$ (dbM No. 1144), leg. G. Mercet, MNMS

27. N 40²5' W 0345' (UTM: 30T VK3674); Madrid, Casa de Campo; (640 m); phytoclimate IV ${ }_{7}$; vegetation Hc/22b: no date $\quad 1$ 요 (dbM No. 1658), leg. Dusmet, MNMS

28. N 40²1' W 0332' (UTM: 30T VK5467); Montarco (= near Rivas-Vaciamadrid); (620 m); phytoclimate IV ${ }_{7}$; vegetation Hc/22b: no date $\quad 1$ ( 1 (dbM No. 1153), leg. Mercet, MNMS

$20^{7} 0^{7} \quad(\mathrm{dbM}$ No. 1161, 1167, 1661), leg. Escalera, MNMS

$10^{\circ} \quad($ dbM No. 1689), BMNH coll. E. Saunders

$06.1890 \quad 1$ (d) $\quad$ (dbM No. 794), leg. Arias, NHMW

$06.1904 \quad 1$ ( $\quad$ (dbM No. 1155, 1156, 1157, 1158, 1159, 1663, 1664, ), leg. Arias, MNMS

$06.1908 \quad 1$ (dbM No. 1660), leg. Arias, MNMS

10.06.1915 $10 \quad$ (dbM No. 1165), leg. Mercet, MNMS

16.06.1914 $10^{2} \quad$ (dbM No. 1761), leg. Dusmet, MZB

19.06.1904 19 (dbM No. 1688), leg. G. Mercet, BMNH coll. E. Saunders

$07.1904 \quad 1 \% \quad$ (dbM No. 1662), leg. Arias, MNMS

25.07.1906 1 우 (dbM No. 1154), MNMS

29. N 40³0' W 033' (UTM: 30T VK5584); Paracuellos de Jarama; (690 m); phytoclimate IV ; vegetation Hc/22b: no date $\quad 10^{7} \quad($ dbM No. 1160), leg. J. Dusmet, MNMS 17.05.1924 $10^{7} \quad$ (dbM No. 1162), leg. Dusmet, MNMS

30. N 40²2' W $03^{\circ} 31^{\prime}$ (UTM: 30T VK5670); Rivas de Jarama; (620 m); phytoclimate IV 7 ; vegetation Hc/22b: no date 1 (dbM No. 1139, 1140, 1141), MNMS

31. N 40 $20^{\prime}$ W $03^{\circ} 30^{\prime}$ (UTM: 30T VK5764); Vaciamadrid (= Rivas-Vaciamadrid); (535 m); phytoclimate IV ; $_{7}$ vegetation Hc/22b: 21.05.1927 $\quad 1 \%$ (dbM No. 1760), leg. Dusmet, MZB 25.05.1926 $\quad 1$ 운. (dbM No. 1142, 1152), leg. Dusmet, MNMS

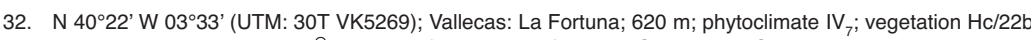

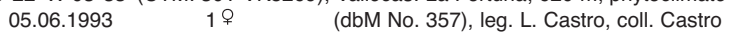




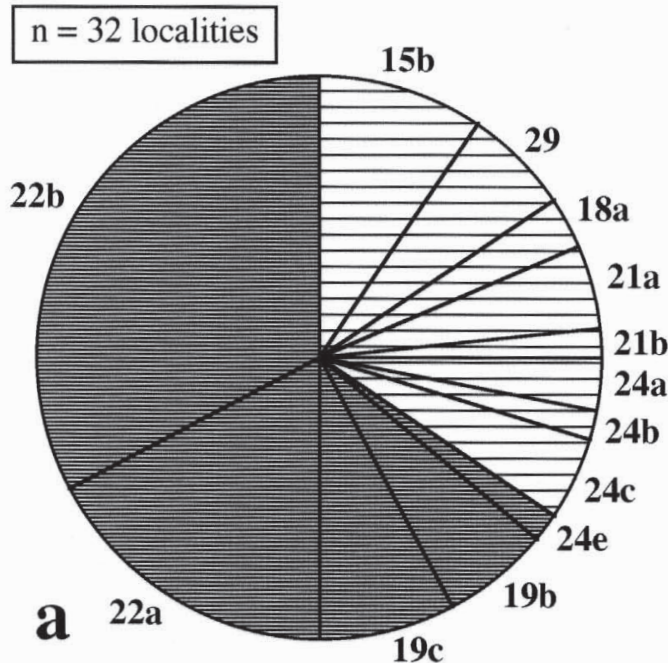

basophilic vegetation series

acidophilic vegetation series
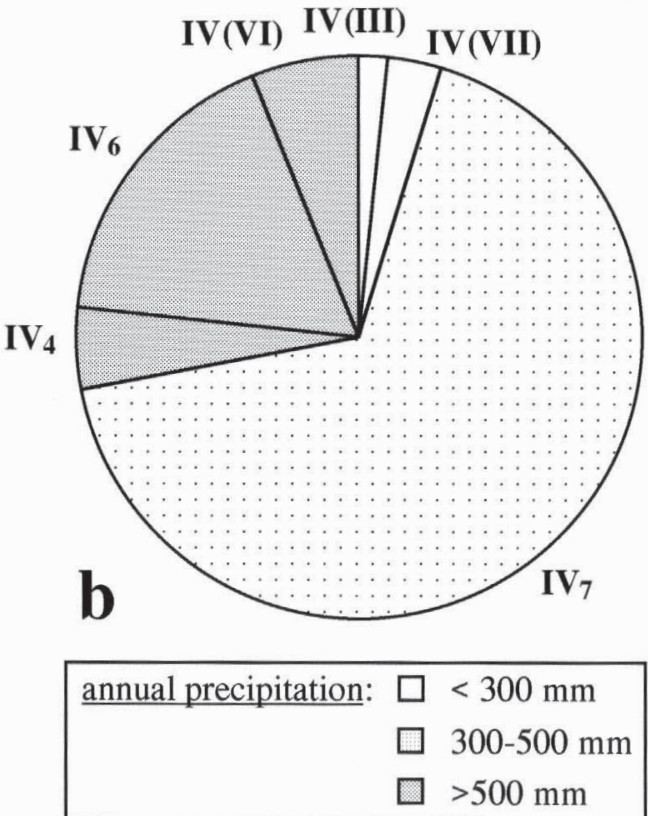

Fig. 3.- a: Proportion of vegetation series of the localities of Ceramius hispanicus and basophilism or acidophilism of the series (after Rivas-Martínez, 1987: 15b Junipereto phoeniceo-thuriferae sigmetum; 18a Luzulo forsteri-Querceto pyrenaica sigmetum; 19b Cephalantero longifoliae-Querceto fagineae sigmetum; 19c Violo willkommi-Querceto fagineae sigmetum; 21a Asplenio onopteridi-Querceto ilicis sigmetum; 21b Viburno tini-Querceto rotundifoliae sigmetum; 22a Junipero thuriferae-Querceto rotundifoliae sigmetum; 22b Bupleuro rigidi-Querceto rotundifoliae sigmetum; 24a Junipero oxycedri-Querceto rotundifoliae sigmetum; 24b Genisto hystricis-Querceto rotundifoliae sigmetum; 24c Pyro bourgaeanae-Querceto rotundifoliae sigmetum; 24e Paeonio coriaceae-Querceto rotundifoliae sigmetum; 29 Rhamno lycioidis-Querceto cocciferae sigmetum) b: Proportion of phytoclimatic subregions (after Allué Andrade, 1987: IV(III) Mediterranean, subarid, hot, with very dry summers; IV(VII) Mediterranean, subarid, moderately hot; $\mathrm{IV}_{4}$ Mediterranean, typical, hot, less dry, with warm winters; $\mathrm{IV}_{7}$ Mediterranean, typical, moderately hot, dry, with cold winters; IV ${ }_{6}$ Mediterranean, typical, moderately hot, less dry; IV(VI) Mediterranean, subhumid, with Central European tendencies) and mean annual precipitation of the localities of $C$. hispanicus.

Fig. 3.- a: Presencia relativa de las series de vegetación en las localidades de Ceramius hispanicus y carácter basófilo o acidófilo de las series (según Rivas-Martínez, 1987: [...] ). b: Caracterización fitoclimática (según Allué Andrade, 1987: IV(III) mediterráneo, subárido, cálido, estíos muy secos; IV(VII) mediterráneo, subárido, moderadamente cálido; IV $_{4}$ mediterráneo, genuino, cálido, menos seco, inviernos cálidos; $\mathrm{IV}_{7}$ mediterráneo, genuino, moderadamente cálido, seco, inviernos frescos, $\mathrm{IV}_{6}$ mediterráneo, genuino, moderadamente cálido, menos seco; IV(VI) mediterráneo, subhúmedo, de tendencia centroeuropea) y precipitación media anual de las localidades de $C$. hispanicus.

flight period of the collected imagines is related to altitude i.e. records from higher altitudes have been made generally later in the season (Fig. 4). The activity of the imagines starts in the first decade of May. Males are only collected up to the end of June while females are active until the end of July (Fig. 5).

\section{Discussion}

The frequency with which $C$. hispanicus has been recorded varies considerably within the
Iberian Peninsula, as indicated by the accumulation of records in the vicinity of Madrid and Teruel, the places of residence of two important Spanish collectors (J.M. Dusmet and L. Castro). Therefore care is required in the interpretation of the data. Nevertheless, the data set probably contains most of the material ever collected and therefore represents present knowledge about the pattern of distribution of the species.

Ceramius hispanicus occurs only in the Mediterranean region of the Iberian Peninsula. In this respect it corresponds to the Afrotropical spe- 


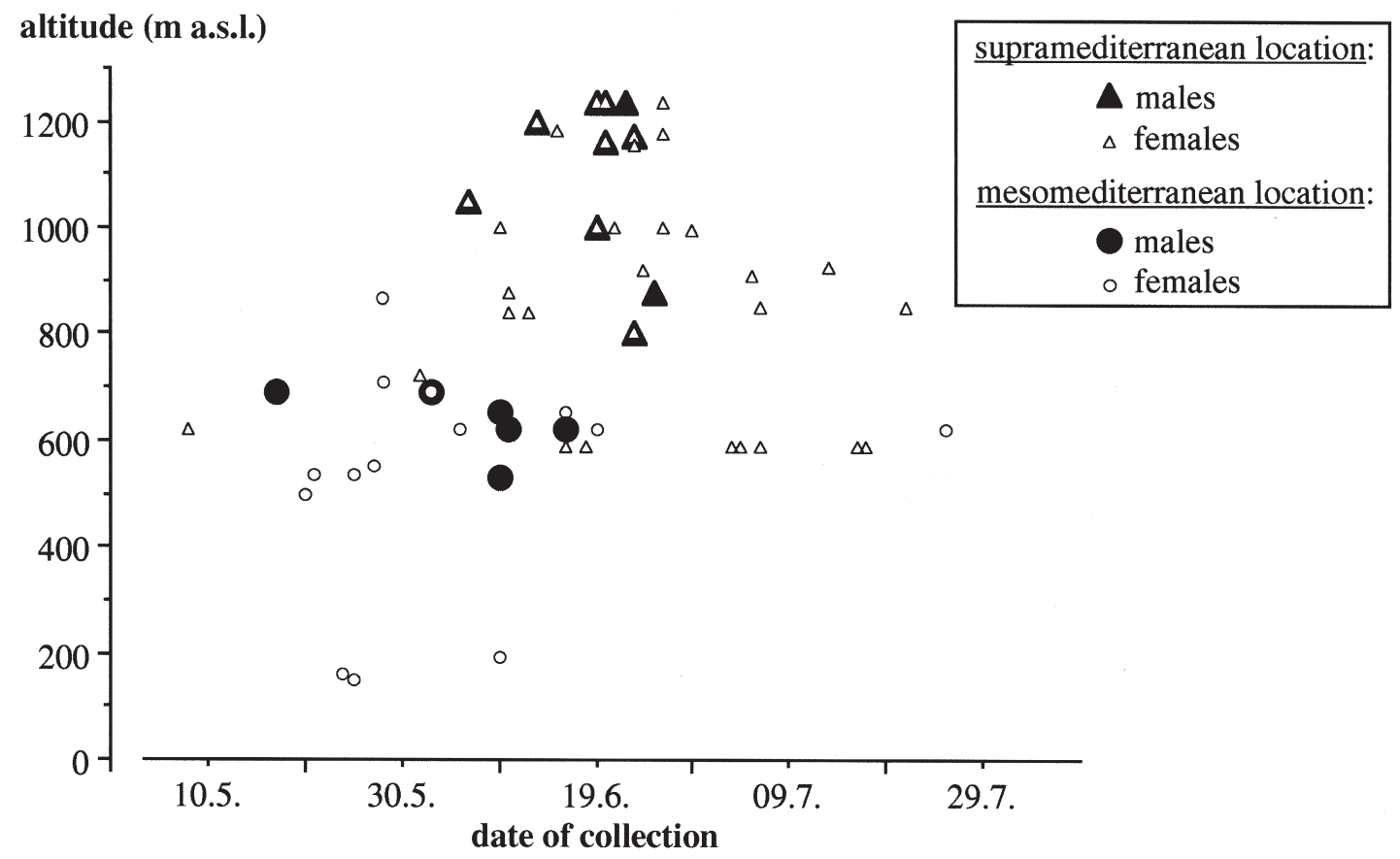

Fig. 4. - Collecting date in relation to altitude for Ceramius hispanicus on the Iberian Peninsula differentiated for story of vegetation and gender (extended collecting times of maximally 8 days given as their median).

Fig. 4.- Fechas de recolección, en relación con la altitud, de Ceramius hispanicus en la Península Ibérica, según pisos bioclimáticos y sexo de los ejemplares (cuando la etiqueta del ejemplar da un periodo [máximo, 8 días] en lugar de una fecha concreta, se ha operado con la fecha central del periodo; Altitude = altitud; date of collection $=$ fecha de recogida; females $=$ hembras; males $=$ machos).

cies of Ceramius, all of which are also restricted to mediterranean-type climate (Gess, 1992). Ceramius hispanicus has only been recorded from the meso- and supramediterranean story of vegetation. The absence of the species from the hotter and more arid thermomediterranean parts of the Iberian Peninsula is probably not the result of missing data, since there are several records of other species of Ceramius from these region (cf. Blüthgen, 1952, 1953, 1956; Dusmet, 1951; Giner-Marí, 1945: 108109; Richards, 1962: 92, 1963; Mauss, unpubl.; Schneider, com. pers. 2000). A single published record from this climatic region (Bischoff, 1933) is doubtful since circumstancial evidence suggests that it was misidentified (unfortunately the specimen could not be found in the Lindberg collection of the Zoological Museum of the University of Helsinki; A. Anders, in lit 2000).

The range of distribution of $C$. hispanicus can be estimated to be $21 \times 10^{4} \mathrm{~km}^{2}$. This is within the size of ranges of other Afrotropical and Palaearctic species of Ceramius, which have a relatively narrow range (areas of 26 species ranging from $0.1 \times 10^{4}$ to $22 \times 10^{4} \mathrm{~km}^{2}$, estimated after Gess, 1992 , 1999 and Mauss, 1998, 1999). In the Afrotropical region, the degree of endemism of the markedly oligolectic species of Ceramius seems to be correlated with their plant association (Gess, 1996: 25, 41). Species associated with Aizoaceae are more widely distributed than those associated with Asteraceae and Papilionaceae (Gess, 1996: 25). In contrast, C. hispanicus is markedly polylectic (Mauss \& Müller, 2000) and it can be assumed that the distribution of potential pollen sources does not limit the species in its distribution. Therefore abiotic and historical factors are probably of greater importance. This assumption has to be qualified by stating that the tendency of $C$. hispanicus to occur more often in basophilic vegetation series may be influenced by the prevalence of flowers of Helianthemum spec. (Cistaceae) in these habitats. Helianthemum was identified as the major pollen source of $C$. hispanicus in the Sierra de Albarracín (Mauss \& Müller, 2000). 


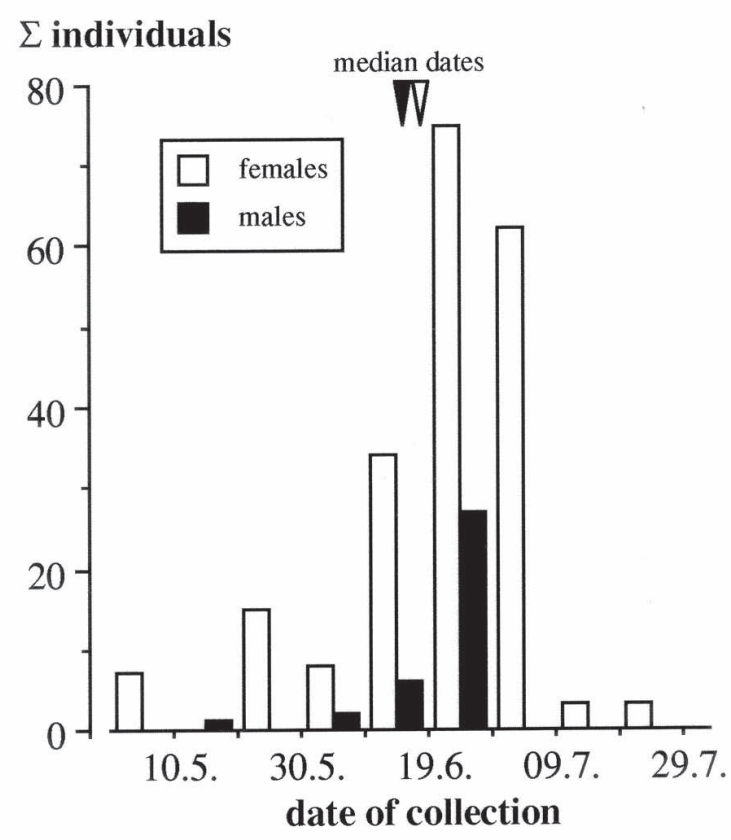

Fig. 5.- Phenology of males and females of Ceramius hispanicus on the Iberian Peninsula.

Fig. 5.- Fenología de los machos y hembras de Ceramius hispanicus en la Península Ibérica (Date of collection $=$ fecha de recogida; female $=$ hembra; male $=$ macho) .

Localities of $C$. hispanicus are characterised by supra- to mesomediterranean temperatures, that is, mean annual temperatures are between $8^{\circ} \mathrm{C}$ and $17^{\circ} \mathrm{C}$, the mean minimum temperature of the coldest month ranges from $-4^{\circ} \mathrm{C}$ to $4^{\circ} \mathrm{C}$, and the mean maximum temperature of the coldest month is between $2^{\circ} \mathrm{C}$ and $14^{\circ} \mathrm{C}$ (cf. Rivas-Martínez, 1987). Mean annual precipitation is generally between 300 and $500 \mathrm{~mm}$ with a dry summer period (cf. Allué Andrade, 1987). Assuming the species to have existed on the Iberian Peninsula during the last period of glaciation, it can be postulated that similar environmental conditions should have existed in the glacial refuge of the species. Such conditions may have been present in the south-western coastal lowlands of the Peninsula (cf. Grichuk, 1992; cf. Velichko \& Isayera, 1992), where a glacial refuge of evergreen Quercus is presumed to have existed (Huntley \& Birks, 1983: 628; cf. Beaulieu et al., 1994). During the mid Holocene (about 5000-6000 yr. BP) summer temperatures were distinctly lower and precipitation was higher than today (Cheddadi et al., 1997). The increase in temperature and decrease in precipitation during the last 5000 years (cf. Cheddadi et al., 1997; Prentice et al., 1998) possibly caused the species to shift its hypothesised original distribution range in a northern direction towards the higher lying ground where it is found today. The current distribution of $C$. hispanicus is probably limited to the north-west by the increasingly atlantic climate.

Ceramius hispanicus has a comparatively small area of distribution being restricted to central and eastern parts of the Iberian Peninsula. Therefore the species is in principle at a relatively high risk of extinction and should be included in conservation programmes. At present $C$. hispanicus does not seem to be endangered since about $50 \%$ of the localities and specimens were recorded during the last 10 years and recently studied populations were large (cf. Mauss \& Müller, 2000).

\section{ACKNOWLEDGEMENTS}

C. van Achterberg (RMNH), J. Carpenter (AMNH), W. Hogenes (ZMAN), S. Lewis (BMNH), C. Martín (MNMS), G. Masó (MZB), B. Merz (ETHZ), D. Schneider (Bonn) and S. Schödl (NHMW) kindly lend material from the collections under their care or their private collections. A. Glowalla (Bonn) helped to identify some of the localities. M. Schindler (Bonn) and R. Paxton (Tübingen) made valuable suggestions on the manuscript. Collection permits were kindly issued by S. Munilla (Diputación General de Aragón).

\section{References}

AlluÉ Andrade, J.L., 1987. Anexo subregiones fitoclimáticas. In: Rivas-Martínez, S. Memoria del Mapa de Series de vegetación de España. In: ICONA (ed.): Publicaciones del Ministerio de Agricultura, Pesca y Alimentación, Serie Técnica. Madrid: 219-223.

Beaulieu, J.-L.d., Andrieu, V., Ponel, P., Reille, M. \& Lowe, J.J., 1994. The Weichselian Late-glacial in southwestern Europe (Iberian Peninsula, Pyrenees, Massif Central, northern Apennines). Journal of Quaternary Science, 9: 101-107.

Bischoff, H., 1933. Inventa entomologica itineris Hispanici et Maroccani, quod a. 1926 fecerunt Harald et Håkan Lindberg. XV. Chrysididae, Cleptinae, Scoliidae, Tiphiidae, Methocidae, Sapygidae, Sphegidae, Masaridae, Vespidae. Societas Scientarum Fennica. Commentationes biologicae, 4(3): 1-7.

BlÜTHGEN, P., 1952. Weitere neue oder bemerkenswerte paläarktische Faltenwespen aus der Zoologischen Staatssammlung in München (Hym. Eumenidae, Masaridae). Mitteilungen der Münchener Entomologischen Gesellschaft, 42: 1-19. 
Blüthgen, P., 1953. Portuguese and Spanish wasps (Hymenoptera, Vespoidea). Memórias e estudos do Museu zoológico da Universidade de Coimbra, 218: $1-23$.

BlÜthgen, P., 1956. Portuguese and Spanish wasps: first supplement. Memórias e Estudos do Museo zoológico da Universidade de Coimbra, 240: 1-23.

Ceballos, G., 1956. Catálogo de los Himenópteros de España. Trabajos del Instituto Español de Entomología: 1-553.

Cheddadi, R., Yu, G., Guinot, J., Harrison, S.P. \& Prentice, I.C., 1997. The climate of Europe 6000 years ago. Climate Dynamics, 13: 1-9.

DiCCIONARIO GEOGRÁFICO DE ESPAÑA, 1956-1961. 1-17, Ediciones del Movimiento. Madrid.

Dusmet, J.M., 1909. Véspidos, Euménidos y Masáridos de España, suplemento segundo. Actas y Memorias del Primer Congreso de Naturalistas Españoles: Zaragoza: 163-184.

Dusmet, J.M., 1935. Cuarenta y cinco años en busca de himenópteros en España: excursiones, consejos y resultados. Memorias de la Sociedad entomológica de España, 4: 1-116.

Dusmet, J.M., 1951. Revisión de los Véspidos y Masáridos de España. Revista de la real Academia de Ciencias, 45: 159-174.

GESS, S.K., 1992. Biogeography of the masarine wasps (Hymenoptera: Vespidae: Masarinae), with particular emphasis on the southern African taxa and on correlations between masarine and forage plant distributions. Journal of Biogeography, 19: 491-503.

GESS, S.K., 1996. The pollen wasps - Ecology and natural history of the Masarinae. Harvard University Press. Cambridge, Massachusetts. 340 pp.

GESS, S.K., 1999. Distribution and ethology of Ceramius damarinus Turner (Hymenoptera: Vespidae: Masarinae) in Namibia. University Kansas Natural History Museum Special Publication, 24: 18-25.

Giner-Marí, J., 1945. Himenópteros de España. Fam. Vespidae, Eumenidae, Masaridae, Sapygidae, Scoliidae y Thynnidae. Instituto Español de Entomología. Madrid. 142 pp.

GrichuK, V.P., 1992. Maximum cooling of the last glaciation (about 20,000 to 18,000 yr B.P.) - Main types of vegetation (ecosystems). In: Frenzel, B., Pécsi, M. \& Velichko, A.A. (eds.). Atlas of Paleoclimates and Paleoenvironments of the Northern Hemisphere. Gustav Fischer. Stuttgart: pl. 57.

Huntley, B. \& BirKs, H.J.B., 1983. An atlas of past and present pollen maps for Europe 0-13000 years ago. Cambridge University press. Cambridge. 667 pp.

MAuss, V., 1998. The identity and distribution of Ceramius auctus (Fabricius, 1804) Vecht, 1970 (Ceramius spiricornis Saussure, 1854 syn. nov.) and Ceramius beaumonti (Giordani Soika, 1957) Richards, 1962
(Hymenoptera, Vespidae, Masarinae). Annales de la Société Entomologique de France, 34(2): 163-183.

Mauss, V., 1999. Taxonomy, biogeography and phylogenetic position of the North African Ceramius maroccanus-complex (Hymenoptera: Vespidae, Masarinae). Entomologica scandinavica, 30: 323348.

Mauss, V. \& Müller, A., 2000. A study of the bionomy of the Spanish pollen wasp Ceramius hispanicus Dusmet (Hymenoptera, Vespidae, Masarinae): Nesting, mating, and flower association. Journal of Hymenoptera Research, 9: 1-17.

Ministerio de Defensa. Secretaría General Técnica (Ed.), 1999. Carta Militar Digital de España Vector Raster/ Centro Geográfico del Ejército. - Escala 1:250.000. Madrid. 93 pp., $1 \mathrm{CD}$.

Nuevo Atlas de España, 1961. Aguilar. Madrid.

Prentice, I.C., Harrison, S.P., Jolly, D. \& Guinot, J., 1998. The climate and biomes of Europe at $6000 \mathrm{yr}$ BP: comparison of model simulations and pollenbased reconstructions. Quaternary Science Reviews, 17: 659-668.

RICHARDS, O.W., 1962. A revisional study of the masarid wasps (Hymenoptera, Vespoidea). British Museum (Natural History). London. 294 pp.

Richards, O.W., 1963. New species of Ceramius Latreille (Hymenoptera, Vespoidea) allied to Ceramius lusitanicus Klug. Zoologische Mededelingen, 38(13): 213-220.

Rivas-MartíneZ, S., 1987. Mapa de Series de vegetación de España 1:400.000 y Memoria. ICONA (ed.), Publicaciones del Ministerio de Agricultura, Pesca y Alimentación, Serie Técnica. Madrid.

SChwerdtfeger, F., 1963. Ökologie der Tiere. Band I Autökologie. Parey. Hamburg. 461 pp.

VelichKo, A.A. \& IsAyerA, L.L., 1992, Maximum cooling of the last glaciation (about 20,000 to $18,000 \mathrm{yr}$ B.P.) - Landscape types. In: Frenzel, B., Pécsi, M. \& Velichko, A.A. (eds.). Atlas of Paleoclimates and Paleoenvironments of the Northern Hemisphere. Gustav Fischer. Stuttgart: pl. 59. 